\title{
Efficacy of betadine vaginal toileting before caesarean section in postoperative infections
}

\author{
Tarang Preet Kaur ${ }^{1 *}$, Asmita M. Rathore ${ }^{2}$, Latika Sahu ${ }^{2}$
}

\begin{abstract}
${ }^{1}$ Department of Obstetrics and Gynecology, All India Institute of Medical Sciences, New Delhi, India
${ }^{2}$ Department of Obstetrics and Gynecology, Maulana Azad Medical College, New Delhi, India
\end{abstract}

Received: 26 March 2020

Accepted: 22 April 2020

\section{*Correspondence:}

Dr. Tarang Preet Kaur,

E-mail: tarang.preet@gmail.com

Copyright: ( $)$ the author(s), publisher and licensee Medip Academy. This is an open-access article distributed under the terms of the Creative Commons Attribution Non-Commercial License, which permits unrestricted non-commercial use, distribution, and reproduction in any medium, provided the original work is properly cited.

\begin{abstract}
Background: The objective of the current study was to evaluate the efficacy of preoperative betadine vaginal toileting in reducing post caesarean infections (endometritis, febrile illness, wound sepsis).

Methods: This prospective longitudinal study was conducted at Maulana Azad Medical College, New Delhi over 3 months among 200 women who underwent caesarean delivery. Inclusion criteria were defined as women undergoing caesarean section. Exclusion criteria included placenta previa, active genital herpes, cord prolapse, chorioamnionitis, allergy to iodine. After taking informed consent, subjects were divided into two groups by simple randomization method using computer generated random numbers- Group 1 (case) - subjects who underwent 5\% povidone iodine sponge stick cleansing in all the fornices and walls of vagina for 30 seconds after foley's catheter insertion and before abdominal scrubbing. Group 2 (control) - subjects who didn't receive betadine vaginal toileting before caesarean section Subjects were followed for 10 days postpartum (or till suture removal/ discharge from hospital, whichever was late). Demographic data, operative details and postoperative parameters were compared between the two groups.

Results: Both groups were matched for baseline patients' characteristics (age, BMI, gestational age, operative time). Women who received preoperative betadine vaginal toileting had markedly less incidence of endometritis (case-3\%, control-10\%, $\mathrm{p}<0.05$ ), overall postoperative morbidity (case-13\%, control-33\%, $\mathrm{p}<0.001$ ). Incidence of postoperative febrile illness (case-6\%, control-12\%, p>0.05) and wound sepsis (case-5\%, control-12\%, $p>0.05$ ) were found to be less but not significant between both groups.

Conclusions: Preoperative vaginal cleansing helps in reducing postoperative morbidity by decreasing incidence of postoperative infection.
\end{abstract}

Keywords: Betadine vaginal toileting, Infections, Post caesarean section

\section{INTRODUCTION}

Caesarean section imposes 5-20-fold increased risk of infections and its related morbidity compared to those undergoing vaginal delivery and thus adding to the economic burden. ${ }^{1}$

Frequently encountered post-caesarean complications include endometritis (6-27\%), febrile illness (5-24\%) and wound infection $(2-9 \%)^{2}$ Post-caesarean infectious morbidity can be attributed to the causal microorganisms ascending from the vagina and cervix into the uterus with hematogenous spread through the exposed edges of the incised uterus. Organisms commonly responsible are Streptolyticus gp A, staphylococcus aureus, E. coli, Klebsiella, Pseudomonas, Proteus, Chlamydia, Peptostreptococcus, Bacteroids, Clostridia. ${ }^{3}$

With the widespread use of preoperative antibiotics, post caesarean infections have been reduced by $60-70 \% .^{4,5}$ Further reduction in infectious morbidity can be attempted by cleansing of vagina with antibacterial 
agents. Only limited data is available that has evaluated and clearly indicated the efficacy of betadine vaginal toiling with concrete parameters. If proven beneficial, it can be incorporated into the local guidelines regarding management of caesarean deliveries by the health care providers.

\section{METHODS}

The present prospective longitudinal study was conducted at Lok Nayak Hospital, Maulana Azad Medical College from August 2017 to November 2017. The study included 200 women who underwent caesarean section.

\section{Inclusion criteria}

- Women undergoing caesarean section.

\section{Exclusion criteria}

- Placenta previa, active genital herpes, cord prolapse, chorioamnionitis, allergy to iodine.

After taking informed consent, subjects were divided into two groups by simple randomization method using computer generated random numbers-

Group 1 (case) - subjects who underwent 5\% povidone iodine sponge stick cleansing in all the fornices and walls of vagina for 30 seconds after foley's catheter insertion and before abdominal scrubbing.

Group 2 (control) - subjects who didn't receive betadine vaginal toileting before caesarean section.
Subjects were followed for 10 days postpartum (or till suture removal/ discharge from hospital, whichever was late). All subjects received preoperative antibiotic shot, abdominal scrubbing with chlorhexidine and 5\% povidone iodine and postoperative antibiotic prophylaxis for 48 hours. Both elective and emergency caesarean sections were included. Demographic data, operative details and post-operative parameters were compared between the two groups. Febrile illness was defined as temperature of $38^{\circ} \mathrm{C}$ or more for minimum of 24 hours following surgery which was not associated with other signs of infection. Clinical endometritis was defined as temperature of $38.5^{\circ} \mathrm{C}$ or more with abnormally foulsmelling discharge or abnormally tender uterus on bimanual examination. Wound sepsis was defined as partial/total separation of wound with serous/purulent wound discharge, induration/tenderness.

\section{Statistical analysis}

Data analysis was done using SPSS software. Qualitative data were expressed in numbers and percentages while qualitative data were expressed in mean and standard deviation. For quantitative variables, student $t$ test was used to test significance of variables and chi square was used to test significance for qualitative variables. A pvalue $<0.05$ was considered statistically significant.

\section{RESULTS}

Baseline demographic maternal characteristics were similar between the two groups as no statistical significance was obtained as presented in Table 1.

Table 1: Demographic comparison of groups.

\begin{tabular}{|c|c|c|c|c|}
\hline Variable & & $\begin{array}{l}\text { Group1 (case) } \\
\text { n=100 }\end{array}$ & $\begin{array}{l}\text { Group } 2 \text { (controls) } \\
n=100\end{array}$ & $\begin{array}{l}\text { p- value } \\
\text { (C.I.- 95\%) }\end{array}$ \\
\hline Maternal age (years) & & $26.85 \pm 4.01$ & $26.26 \pm 3.72$ & 0.31 \\
\hline \multirow{3}{*}{ BMI $(\%)$} & Underweight $(<18.5)$ & 1 & 1 & 1.0 \\
\hline & Normal weight (18.5-24.9) & 91 & 93 & 0.6 \\
\hline & Overweight/obese $(\geq 25)$ & 8 & 6 & 0.5 \\
\hline \multirow{4}{*}{ Gestational age (\%) } & $<34$ weeks & 3 & 7 & 0.19 \\
\hline & 34-37 weeks & 16 & 13 & 0.54 \\
\hline & $37-40$ & 55 & 63 & 0.25 \\
\hline & $>40$ weeks & 26 & 17 & 0.19 \\
\hline \multirow[t]{2}{*}{ Parity (\%) } & Primiparous & 44 & 43 & 0.88 \\
\hline & Multiparous & 56 & 57 & 0.88 \\
\hline $\begin{array}{l}\text { Preoperative haemoglobin } \\
(\text { Mean } \pm \text { SD) }\end{array}$ & & $11.4 \pm 1.46$ & $11.43 \pm 1.48$ & 0.88 \\
\hline $\begin{array}{l}\text { Postoperative haemoglobin } \\
(\text { Mean } \pm \text { SD) }\end{array}$ & & $11.6 \pm 1.38$ & $11.02 \pm 1.36$ & 0.87 \\
\hline
\end{tabular}

It included maternal age, BMI, gestational age at the time of delivery, parity, preoperative and postoperative haemoglobin. Labor and caesarean section characteristics were studied between the two groups as shown in Table 
2. No significant difference was found in terms of number of subjects in labor, length of labor after admission, number of pelvic examinations done before caesarean delivery, rupture of membranes. Also, no statistically significant difference was observed between the number of elective or emergency caesarean sections, whether it was performed by junior resident or senior resident or consultant, operative time, presence of meconium, number of blood transfusions.

Table 2: Labor and caesarean characteristics.

\begin{tabular}{|c|c|c|c|c|}
\hline Variable & & $\begin{array}{l}\text { Group 1-case } \\
(n=100)\end{array}$ & $\begin{array}{l}\text { Group 2-control } \\
(\mathrm{n}=100)\end{array}$ & p-value \\
\hline No labor $(\%)$ & & 25 & 20 & 0.40 \\
\hline In Labor (\%) & & 75 & 80 & 0.40 \\
\hline \multirow{3}{*}{ Length of labor after admission } & $<12$ hours & 38 & 43 & 0.47 \\
\hline & $12-24$ hours & 20 & 15 & 0.35 \\
\hline & $>24$ hours & 17 & 22 & 0.70 \\
\hline $\begin{array}{l}\text { Number of pelvic examinations done before caesarean } \\
(\text { Mean } \pm \text { SD) }\end{array}$ & & $4.7 \pm 1.4$ & $4.4 \pm 1.4$ & 0.23 \\
\hline Rupture of membranes $(\%)$ & & 52 & 55 & 0.67 \\
\hline \multirow{2}{*}{ Type of LSCS (\%) } & Elective & 18 & 15 & 0.57 \\
\hline & Emergency & 82 & 85 & 0.57 \\
\hline Operative time (Mean \pm SD) & & $60.21 \pm 11.28$ & $59.6 \pm 15.2$ & 0.75 \\
\hline Blood transfusions intra/postop (\%) & & 5 & 8 & 0.39 \\
\hline \multirow{3}{*}{ Surgeon $(\%)$} & SR & 86 & 85 & 0.84 \\
\hline & JR & 11 & 13 & 0.31 \\
\hline & Consultant & 3 & 1 & 0.31 \\
\hline \multirow{4}{*}{ Birth weight (\%) } & $<2 \mathrm{~kg}$ & 8 & 18 & 0.03 \\
\hline & $2-2.5 \mathrm{~kg}$ & 21 & 16 & 0.36 \\
\hline & $2.5-3 \mathrm{~kg}$ & 39 & 37 & 0.77 \\
\hline & $>3 \mathrm{~kg}$ & 32 & 29 & 0.6 \\
\hline $\operatorname{MSL}(\%)$ & & 17 & 27 & 0.08 \\
\hline
\end{tabular}

Table 3: Postoperative outcomes.

\begin{tabular}{|c|c|c|c|c|}
\hline Variable & & $\begin{array}{l}\text { Group 1-case } \\
(n=100)\end{array}$ & $\begin{array}{l}\text { Group 2-control } \\
(n=100)\end{array}$ & $\begin{array}{l}\text { p-value } \\
\text { (C.I.-95\%) }\end{array}$ \\
\hline \multirow{3}{*}{ Postoperative stay (\%) } & 4 days & 59 & 44 & 0.03 \\
\hline & 5-10 days & 33 & 42 & 0.19 \\
\hline & $>10$ & 8 & 14 & 0.17 \\
\hline Febrile illness (\%) & & 6 & 12 & 0.139 \\
\hline Clinical endometritis (\%) & & 3 & 10 & 0.045 \\
\hline Wound Sepsis (\%) & & 5 & 12 & 0.077 \\
\hline Resuturing $(\%)$ & & 4 & 10 & 0.097 \\
\hline Readmission $(\%)$ & & 2 & 6 & 0.15 \\
\hline Overall postoperative morbidity (\%) & & 13 & 33 & 0.0008 \\
\hline
\end{tabular}

Highly statistically significant difference was obtained in the incidence of overall postoperative morbidity in the case group (13\%) when compared to control group $(33 \%)$; p value $=0.0008$. Significant number of subjects from case group were discharged on $4^{\text {th }}$ postoperative day when compared to the control group. In study hospital, authors follow a protocol of discharging asymptomatic post caesarean patient after 72 hours. Postoperative clinical endometritis was observed in 3 of 100 cases $(3 \%)$ versus 10 of 100 controls $(10 \%)$; p value $=0.045$. No significant difference was observed in the incidence of febrile illness, wound sepsis, requirement of resuturing, need for readmission as show in Table 3. Study outcomes were also studied in the patients with ruptured membranes as shown in Table 4. Among these women, significant differences in the rate of endometritis were noted in the control group compared with the case group ( $9 \%$ versus $0 \%$; p value $=0.002$ ). Significant difference was not obtained in fever or wound infection. Meconium presence was found significantly in a greater number of subjects in control group and could be a confounding factor (case-28.8\%, control-49.1\%, p value=0.03). 
Similar outcomes were also compared in the subjects who were in labour during caesarean delivery as presented in Table 5. It was seen that incidence of febrile illness (case$2.6 \%$, control-15\%; p value-0.007) and endometritis (case-1.3\%, control-12.5\%; p value-0.006) was significantly reduced in the case group when compared to the control group.

Table 4: Study outcomes in patients with ruptured membranes at the time of caesarean section.

\begin{tabular}{|c|c|c|c|c|}
\hline Variable & & $\begin{array}{l}\text { Group 1-case } \\
(n=52)\end{array}$ & $\begin{array}{l}\text { Group 2-control } \\
(\mathrm{n}=55)\end{array}$ & $\begin{array}{l}\text { p-value } \\
\text { (C.I- 95\%) }\end{array}$ \\
\hline Age (years) & & $27.11 \pm 4.17$ & $25.7 \pm 4.23$ & 0.08 \\
\hline \multirow{3}{*}{ BMI n (\%) } & Underweight $(<18.5)$ & $0(0 \%)$ & $1(1.8 \%)$ & 0.33 \\
\hline & Normal weight (18.5-24.9) & $47(90 \%)$ & $51(92.7 \%)$ & 0.62 \\
\hline & Overweight/obese $(\geq 25.0)$ & $5(10 \%)$ & $3(5.4 \%)$ & 0.37 \\
\hline $\begin{array}{l}\text { Gestational diabetes mellitus/ } \\
\text { overt diabetes mellitus }\end{array}$ & & $7(13.4 \%)$ & $1(1.81 \%)$ & 0.023 \\
\hline Anemia n (\%) & & $11(21 \%)$ & $19(34.5 \%)$ & 0.12 \\
\hline Meconium presence $\mathrm{n}(\%)$ & & $15(28.8 \%)$ & $27(49.1 \%)$ & 0.03 \\
\hline \multirow{3}{*}{ Operative time $\mathrm{n}(\%)$} & $\leq 60$ minutes & $38(73.1 \%)$ & $48(87.3 \%)$ & 0.06 \\
\hline & $60-70$ minutes & $12(23 \%)$ & $6(10.9 \%)$ & 0.09 \\
\hline & $>70$ minutes & $2(3.8 \%)$ & $1(1.8 \%)$ & 0.53 \\
\hline Endometritis n (\%) & & $0(0 \%)$ & $9(16.3 \%)$ & 0.002 \\
\hline Febrile illness n (\%) & & $2(3.8 \%)$ & $8(14.5 \%)$ & 0.058 \\
\hline Wound sepsis n (\%) & & $3(5.7 \%)$ & $6(10.9 \%)$ & 0.33 \\
\hline
\end{tabular}

Table 5: Study outcomes in patients in labor at the time of caesarean section.

\begin{tabular}{|c|c|c|c|c|}
\hline Variable & & $\begin{array}{l}\text { Group 1-case } \\
(n=75)\end{array}$ & $\begin{array}{l}\text { Group 2-control } \\
(n=80)\end{array}$ & $\begin{array}{l}\text { p-value } \\
\text { (C.I.-95\%) }\end{array}$ \\
\hline Age (years) & & $26.6 \pm 3.93$ & $26.01 \pm 3.80$ & 0.93 \\
\hline \multirow{3}{*}{ BMI n (\%) } & Underweight (<18.5) & $1(1.33)$ & $1(1.3 \%)$ & 1.0 \\
\hline & Normal weight (18.5-24.9) & $68(90.6 \%)$ & $68(93.7 \%)$ & 0.34 \\
\hline & Overweight/obese $(\geq 25)$ & $6(8 \%)$ & $10(12.5 \%)$ & 0.4 \\
\hline $\begin{array}{l}\text { Gestational diabetes mellitus/ } \\
\text { overt diabetes mellitus } \mathrm{n}(\%)\end{array}$ & & $8(10.6 \%)$ & $6(80 \%)$ & 0.50 \\
\hline Anemia $\mathrm{n}(\%)$ & & $21(28 \%)$ & $27(33.1 \%)$ & 0.44 \\
\hline \multirow{4}{*}{$\begin{array}{l}\text { Spontaneous/induced labor to } \\
\text { caesarean interval } \mathrm{n}(\%)\end{array}$} & $<10$ hours & $35(46.6 \%)$ & $42(52.5 \%)$ & 0.56 \\
\hline & 10-20 hours & $19(25.3 \%)$ & $16(21.05 \%)$ & 0.53 \\
\hline & 20-30 hours & $9(12 \%)$ & $11(14.4 \%)$ & 0.66 \\
\hline & $>30$ hours & $12(16 \%)$ & $11(14.4 \%)$ & 0.78 \\
\hline $\begin{array}{l}\text { Ruptured membranes during } \\
\text { caesarean section } \mathrm{n}(\%)\end{array}$ & & $52(70.3 \%)$ & $56(70 \%)$ & 0.96 \\
\hline Meconium presence $\mathrm{n}(\%)$ & & $58(22.6 \%)$ & $17(35 \%)$ & 0.09 \\
\hline \multirow{3}{*}{ Operative time n $(\%)$} & $\leq 60$ minutes & $58(77.3 \%)$ & $64(80.0 \%)$ & 0.68 \\
\hline & $60-70$ minutes & $15(20 \%)$ & $14(17.5 \%)$ & 0.69 \\
\hline & $>70$ minutes & $2(2.6 \%)$ & $2(2.5 \%)$ & 0.96 \\
\hline Febrile illness n (\%) & & $2(2.6 \%)$ & $12(15 \%)$ & 0.007 \\
\hline Endometritis n (\%) & & $1(1.3 \%)$ & $10(12.5 \%)$ & 0.006 \\
\hline Wound sepsis n (\%) & & $5(6.6 \%)$ & $7(8.75 \%)$ & 0.62 \\
\hline
\end{tabular}

Table 6: Neonatal outcomes.

\begin{tabular}{|lllll|}
\hline Variable & & Group1 (case) $(\mathbf{n = 1 0 0})$ & Group 2 (controls) $(\mathbf{n = 1 0 0 )}$ & p- value (C.I.- 95\%) \\
\hline \multirow{3}{*}{ Birth weight (\%) } & $<2 \mathrm{~kg}$ & 8 & 18 & 0.03 \\
\cline { 2 - 6 } & $2-2.5 \mathrm{~kg}$ & 21 & 16 & 0.36 \\
\cline { 2 - 6 } & $2.5-3 \mathrm{~kg}$ & 39 & 37 & 0.77 \\
\cline { 2 - 6 } & $>3 \mathrm{~kg}$ & 32 & 29 & 0.6 \\
\hline NICU stay (n) & & 12 & 6 & 0.04 \\
\hline Neonatal sepsis (n) & & 2 & & 0.14 \\
\hline
\end{tabular}


As depicted in Table 6, significantly decreased number of babies were admitted in NICU whose mothers received preoperative betadine vaginal toileting. However significantly greater number of low birth weight babies were born in the control group which could be a confounding factor.

\section{DISCUSSION}

According to the results of this study, preoperative vaginal toileting has shown to be beneficial in reducing postoperative morbidity and infections. Infection is an important factor influencing early hospital discharge, patient satisfaction, postoperative pain. Ascending cervico-vaginal infection has been shown to be an important factor attributing to it.

The concept of preoperative vaginal cleansing has been proven to reduce vaginal bacterial count and thus postoperative infectious morbidity and is used in cases of abdominal hysterectomy since 1970. Various studies have been conducted to evaluate the efficacy of vaginal cleansing with antibacterial agents before caesarean section in post-operative infections but with conflicting outcomes due to various limitations. ${ }^{6-9}$ Amstey et al reported elimination of anaerobic gram positive bacilli and significant reduction of gram negative bacilli and aerobic and anaerobic gram positive cocci with preoperative vaginal cleansing. ${ }^{10}$ Starr and colleagues also proved decreased incidence of endometritis with preoperative vaginal cleansing with povidone iodine. ${ }^{7}$ Although this study didn't include participants with chorioamnionitis and those who had undergone emergency caesarean section thus contributing to the weakness of the study. Role of preoperative vaginal toileting in reducing endometritis was also proved by Asghania et al. ${ }^{6}$ Cochrane review in 2014 by Hass DM et al, also showed that vaginal cleansing with povidone iodine significantly prevented postoperative endometritis. ${ }^{11}$ This effect was observed especially in cases with ruptured membranes or in active labor. Another recent meta-analysis by The American College of Obstetricians and Gynecologists (ACOG) in 2017 has also proved that vaginal cleansing before caesarean section reduces the incidence of endometritis compared with no such cleansing. ${ }^{2}$ This study also supported the outcomes of the above-mentioned studies.

The present study had several strengths such as both elective and emergency caesarean sections were included. Most of the studies have been done on elective cases. Secondly, both groups were similar in respect to the factors contributing to the postoperative infections such as incidence of ruptured membranes, number of vaginal examinations, labour to caesarean interval, incidence of patients who were in labour at the time of delivery, number of subjects with diabetes and anaemia. This study showed significant reduction in endometritis, especially in patients with ruptured membranes and patients in labour at the time of delivery. This study also showed significant reduction in febrile illness in patients in labour who received preoperative vaginal toileting. This study did not show significant reduction in overall risk of febrile illness or wound sepsis as shown in most of the previous studies conducted. ${ }^{6,7}$

This study had small sample size, thus contributing to its limitation.

\section{CONCLUSION}

Preoperative vaginal cleansing is an easy and inexpensive method and its use should be promoted in both elective and emergency caesarean sections as it has been proved to be efficacious in reducing overall postoperative morbidity and especially postoperative endometritis in this study.

Preoperative vaginal cleansing helps in reducing postoperative morbidity by decreasing incidence of postoperative infection.

\section{ACKNOWLEDGMENTS}

All the authors made a substantial contribution to conception and design of manuscript. Acquisition, interpretation and analysis of data and drafting of manuscript was done by TPK and AR. It was critically revised by AR and LS. Final approval was done by all the authors. All the authors agree to be accountable to all aspect of work including its accuracy and integrity.

Authors express sincere thanks to all the subjects who agreed to participate in the study.

Funding: No funding sources

Conflict of interest: None declared

Ethical approval: The study was approved by the Institutional Ethics Committee

\section{REFERENCES}

1. Declercq E, Barger M, Cabral HJ, Evans SR, Kotelchuck M, Simon C, et al. Maternal outcomes associated with planned primary cesarean births compared with planned vaginal births. Obstet Gynecol. 2007;109:669-77.

2. Caissutti C, Saccone G, Zullo F, Quist-Nelson J, Felder L, Ciardulli A, et al. Vaginal cleansing before cesarean delivery: a systematic review and metaanalysis. Obstet Gynecol. 2017;130(3):527-38.

3. Nandi JK, Saha DP, Pal S, Barman S, Mitra A. Antiseptic vaginal preparation before cesarean delivery to reduce post-operative infection: a randomized controlled trial. JMSCR. 2015;3:4310-5.

4. French LM, Smaill FM. Antibiotic regimens for endometritis after delivery. The Cochrane Database Syst Rev. 2004;2:Art. No.: CD001067. 
5. Smaill FM, Grivell RM. Antibiotic prophylaxis versus no pro- phylaxis for preventing infection after cesarean section. The Cochrane Database Syst Rev. 2014:Art. No.:CD007482.

6. Asghania M, Mirblouk F, Shakiba M, Faraji R. Preoperative vaginal preparation with povidoneiodine on post-caesarean infectious morbidity. J Obstet Gynaecol. 2011;31:400-3.

7. Starr RV, Zurawski J, Ismail M. Preoperative vaginal preparation with povidone-iodine and the risk of post-cesarean endometritis. Obstet Gynecol. 2005;105:1024-9.

8. Guzman MA, Prien SD, Blann DW. Post-cesarean related infection and vaginal preparation with povidone-iodine revisited. Prim Care Update Obstet Gynecol. 2002;9:206-9.

9. Memon S, Qazi RA, Bibi S, Parveen N. Effect of preoperative vaginal cleansing with an antiseptic solution to reduce post caesarean infectious morbidity. J Pak Med Assoc. 2011;61:1179-83.

10. Amstey MS, Jones AP. Preparation of the vagina for surgery. A comparison of povidone-iodine and saline solution. JAMA. 1981;245:839-41.

11. Haas DM, Morgan S, Contreras K. Vaginal preparation with antiseptic solution before cesarean section for preventing postoperative infections. Cochrane Database Syst Rev. 2014;12:CD007892.

Cite this article as: Kaur TP, Rathore AM, Sahu L. Efficacy of betadine vaginal toileting before caesarean section in postoperative infections. Int $\mathbf{J}$ Reprod Contracept Obstet Gynecol 2020;9:2457-62. 